\title{
EFETIVIDADE DAS NORMAS CONSTITUCIONAIS E SENTENÇAS COM EFEITOS ADITIVOS NA JUSTIÇA CONSTITUCIONAL PORTUGUESA E BRASILEIRA
}

\author{
EFFECTIVENESS OF CONSTITUTIONAL STANDARDS AND SENTENCES \\ WITH ADDITIVE EFFECTS ON CONSTITUTIONAL JUSTICE AND BRAZILIAN \\ PORTUGUESE
}

\section{Camila Silva de Amorim ${ }^{1}$}

SUMÁRIO: Introdução; 1. Efetividade das normas constitucionais e jurisdição constitucional; 1.1 Hermenêutica das normas constitucionais; 1.2 Eficácia e efetividade das normas constitucionais; 1.3 Normas constitucionais e jurisdição constitucional; 2. Omissão legislativa e ascensão do judiciário; 2.1 Omissão normativa inconstitucional e responsabilidade do Estado; 2.2 Ascensão do judiciário; 3. Sentenças intermédias e efeitos aditivos versus controle de constitucionalidade; 3.1 Sentenças intermédias e manipulativas; 3.2 Sentenças com efeitos aditivos; Considerações Finais; Referências das fontes citadas.

RESUMO: A partir da análise da eficácia ou da efetividade das normas jurídicas no exercício da jurisdição constitucional cumpre analisar o papel cada vez mais marcante nos casos de omissão legislativa do órgão constitucional. Da comparação entre a legislação do Brasil e do país irmão, Portugal, dada a influência deste em nosso controle de constitucionalidade, percebermos que o chamado ativismo judicial é notório na jurisprudência pátria. Assim, a análise hermenêutica constitucional nos permite traçar uma posição mais crítica sobre a famigerada atuação judicial do órgão de cúpula a quem incumbe à guarda da Constituição.

Palavras-chaves: Controle; Hermenêutica; Jurisdição Constitucional; Ativismo.

\footnotetext{
${ }^{1}$ Advogada. Professora do Centro Universitário de Brasília (UNICEUB). Graduada em Direito pelo Centro Universitário de Brasília. Pós-graduada em Direito Processual Civil pela Universidade do Sul de Santa Catarina (UNISUL) e pela Fundação de Ensino Superior do Ministério Público do Distrito Federal e Territórios (FESMPDFT). Mestre em Direito Constitucional pela Universidade de Direito de Coimbra, Portugal. Doutoranda pela Universidade de Direito de Coimbra, Portugal. E-mail amorim.camila2012@gmail.com.
} 
AMORIM, Camila Silva de. Efetividade das normas constitucionais e sentenças com efeitos aditivos na justiça constitucional portuguesa e brasileira. Revista Eletrônica Direito e Política, Programa de Pós-Graduação Stricto Sensu em Ciência Jurídica da UNIVALI, Itajaí, v.10, n.2, $1^{\circ}$ quadrimestre de 2015. Disponível em: www.univali.br/direitoepolitica - ISSN 1980-7791.

ABSTRACT: From the analysis of the efficacy or effectiveness of legal rules in exercise of constitutional jurisdiction necessary to examine the increasingly influential role in cases of legislative omission of the constitutional institution. When comparing the laws of Brazil and brother country, Portugal, given its influence in our constitutional control, to realize that the called judicial activism is striking in the homeland jurisprudence. Thus, the constitutional hermeneutic analysis allows us to draw a more critical stance on the notorious judicial action organ dome which is responsible for safeguarding the Constitution.

Keywords: Control; Hermeneutics; Constitutional Jurisdiction; Activism.

\section{INTRODUÇÃO}

Compreender a eficácia ou a efetividade das normas jurídicas constitucionais dentro do controle de constitucionalidade não é uma tarefa fácil. A jurisdição constitucional portuguesa e a brasileira trazem certa complexidade na avaliação e no estudo das técnicas e métodos que as Cortes, responsáveis pela guarda da Constituição, vêm a utilizar nos últimos tempos.

Nesse trabalho, dentro de uma análise comparativa diante da influência do direito português no direito brasileiro no controle da omissão, pretende-se num primeiro momento analisar a nova hermenêutica constitucional e a eficácia/efetividade das normas constitucionais nas sociedades modernas.

Em seguida, parte-se à análise da inconstitucionalidade por omissão e dos institutos correlatos a essa figura com escopo de compreender em que consiste o desempenho do julgador no contexto da omissão com vistas à efetivação da Carta Maior.

E por fim, após breve análise da interpretação da norma e da omissão dentro da eficácia das normas constitucionais, em notas conclusivas, tem-se a discussão a respeito das sentenças com efeitos aditivos proferidas pelo poder jurisdicional como legislador positivo e a consequente legitimidade dessa atuação. 
AMORIM, Camila Silva de. Efetividade das normas constitucionais e sentenças com efeitos aditivos na justiça constitucional portuguesa e brasileira. Revista Eletrônica Direito e Política, Programa de Pós-Graduação Stricto Sensu em Ciência Jurídica da UNIVALI, Itajaí, v.10, n.2, $1^{\circ}$ quadrimestre de 2015. Disponível em: www.univali.br/direitoepolitica - ISSN 1980-7791.

\section{EFETIVIDADE DAS NORMAS CONSTITUCIONAIS E JURISDIÇÃO CONSTITUCIONAL}

\subsection{Hermenêutica das normas constitucionais}

Normas constitucionais são todas aquelas que integram uma constituição rígida. São criadas para reger relações sociais, condutas humanas; enfim, para serem aplicadas. A aplicabilidade exprime uma possibilidade que consiste na atuação concreta da norma, ou seja, enquadrar um caso concreto a norma jurídica adequada, submissão das prescrições da lei na vida real. ${ }^{2}$

A norma constitucional assumiu status de norma jurídica de hierarquia superior no decorrer da história do constitucionalismo.

Sob a perspectiva do liberalismo, entendia-se a lei como mecanismo de demarcação da esfera de intervenção estatal, uma ferramenta de contenção da ideologia que norteou o Estado absolutista. As constituições, por seu turno, adquiriram um matiz de instrumento quase que exclusivamente regulatório da atividade do Estado, em vista da necessidade de organização das competências e de limitação do poder em face dos direitos fundamentais recentemente reconhecidos. Nessa época, a filosofia positivista atribuía ao juiz o papel de mero ventríloquo, a quem cabia apenas enunciar o conteúdo linguístico dos Códigos, cuja literalidade supostamente seria capaz de dar solução aos mais variados

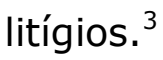

Uma das grandes mudanças de paradigma ocorridas ao longo do século XX foi a atribuição à norma constitucional do status de norma jurídica. Superou-se, assim, o modelo que vigorou na Europa até meados do século passado, no qual, a constituição era vista como um documento essencialmente político, um convite à atuação dos Poderes Públicos. A concretização de suas propostas ficava invariavelmente condicionada a liberdade de conformação do legislador ou à

\footnotetext{
2 SILVA, José Afonso da. Aplicabilidade das normas constitucionais. 7 ed. São Paulo: Malheiros, 2007, p. 44-51.

${ }^{3}$ Sobre o tema, vide CARVALHO NETTO, Menelick de. Requisitos paradigmáticos da interpretação jurídica sob o paradigma do Estado democrático de direito. Revista de Direito Comparado, Belo Horizonte, n. 3, mai. 1999.
} 
AMORIM, Camila Silva de. Efetividade das normas constitucionais e sentenças com efeitos aditivos na justiça constitucional portuguesa e brasileira. Revista Eletrônica Direito e Política, Programa de Pós-Graduação Stricto Sensu em Ciência Jurídica da UNIVALI, Itajaí, v.10, n.2, 10 quadrimestre de 2015. Disponível em: www.univali.br/direitoepolitica - ISSN 1980-7791.

discricionariedade do administrador. Ao Judiciário não se reconhecia qualquer papel relevante do conteúdo da Constituição. Uma vez investida na condição de norma jurídica, a norma constitucional passou a desfrutar dos atributos essenciais do gênero, dentre os quais o da imperatividade. ${ }^{4}$

Trata-se do que a doutrina tem reconhecido como neoconstitucionalismo. Nos dizeres de Miguel Carbonell:

El neoconstitucionalismo, entendido como el término o concepto que explica um fenômeno reciente dentro del Estado Constitucional contemporâneo, parece contar cada día com más seguidores, sobre todo em el ámbito de la cultura jurídica italiana y española, así como en diversos países de América Latina (particularmente em los grandes focos culturales de Argentina, Brasil, Colombia y Mexico). Con todo, se trata de un fenómeno escassamente estudiado, cuya cabal comprensión seguramente tomará todavia algunos años. 5

Neste novo contexto, o de neoconstitucionalismo, a intepretação judicial de cláusulas constitucionais vagas e abertas, como os princípios da dignidade da pessoa humana, da moralidade administrativa, da livre iniciativa e proporcionalidade, torna-se essencial para a definição de questões socialmente controvertidas e/ou tecnicamente complexas. ${ }^{6}$

A titulo exemplificativo cita-se a constitucionalidade de pesquisa de célulastronco embrionárias, direito ao casamento entre pessoas do mesmo sexo, demarcação de territórios indígenas, entre outras questões que vem sendo

${ }^{4}$ BARROSO, Luís Roberto. A doutrina brasileira da efetividade. Constituição e democracia: estudos em homenagem ao professor J. J. Gomes Canotilho. São Paulo: Malheiros, 2006, p. 435-448. No mesmo sentido, SARMENTO, Daniel. Interpretação constitucional, pré-compreensão e capacidades institucionais do intérprete. In Intepretação Constitucional. Reflexões sobre (a nova hermenêutica). Salvador: Edições JusPodivm, 2010, p. 141. "Muita coisa mudou no Brasil nos últimos 20 anos no campo da intepretação constitucional. Se, no cenário pretérito, em que a Constituição era pouco mais do que a 'folha de papel' de Lassale, o tema não tinha maior relevância prática, ele assume uma importância central no atual ambiente institucional brasileiro, que é marcado por diversos fenômenos relevantes e inter-relacionados, como a constitucionalização do Direito, a judicialização da política e a progressiva incorporação à prática judicial de métodos e 'estilos' hermenêuticos mais dinâmicos e flexíveis."

${ }^{5}$ CARBONELL, Miguel. Neoconstitucionalismo: elementos para uma definición. In 20 anos da Constituição brasileira. São Paulo: Saraiva, 2009, p. 197.

${ }^{6}$ SARMENTO, Daniel. Interpretação constitucional, pré-compreensão e capacidades institucionais do intérprete. In Intepretação Constitucional. Reflexões sobre (a nova hermenêutica). Salvador: Edições JusPodivm, 2010, p. 142. 
AMORIM, Camila Silva de. Efetividade das normas constitucionais e sentenças com efeitos aditivos na justiça constitucional portuguesa e brasileira. Revista Eletrônica Direito e Política, Programa de Pós-Graduação Stricto Sensu em Ciência Jurídica da UNIVALI, Itajaí, v.10, n.2, 10 quadrimestre de 2015. Disponível em: www.univali.br/direitoepolitica - ISSN 1980-7791.

debatidas no judiciário brasileiro. Da mesma forma, o Tribunal Constitucional Português enfrenta, por exemplo, questões relacionadas à implementação do direito ao aborto e adaptação às regras da comunidade europeia, sobretudo no aspecto econômico.

E a busca de solução para questões controvertidas se dá na interpretação de conceitos jurídicos indeterminados, no reconhecimento da normatividade dos princípios, no uso da ponderação de normas constitucionais baseada no princípio instrumental da razoabilidade e na argumentação (dever de fundamentação) das decisões. ${ }^{7}$

Essa tarefa não é fácil, com ressaltado por Miguel Carbonell, ${ }^{8}$ envolve a constitucionalização do ordenamento jurídico (neoconstitucionalismo) e tem como pressupostos uma constituição rígida, a garantia jurisdicional da constituição e a força vinculante da constituição. O que leva a "sobreinterpretación de la Constitución" como denominado pelo renomado autor no Estado Constitucional Contemporâneo.

O direito é um fenômeno complexo e concretizar uma Constituição implica em compreender uma das questões mais importantes em que os jurisfilósofos do mundo vêm se debruçando em matéria de hermenêutica constitucional e que também visa explicar a atuação do judiciário nesta vertente: a racionalidade das decisões judiciais. ${ }^{9}$

\footnotetext{
7 BARROSO, Luís Roberto. Novos paradigmas e categorias da interpretação constitucional. In Intepretação Constitucional. Reflexões sobre (a nova hermenêutica). Salvador: Edições JusPodivm, 2010, p. 165-168.

8 CARBONELL, Miguel. Neoconstitucionalismo: elementos para uma definición. In 20 anos da Constituição brasileira. São Paulo: Saraiva, 2009, p. 199-203. Ainda, segundo o autor: "Además, se los jueces se las tiene que ver com la dificultad de trabajar con 'valores' que están constitucionalizados y que requerien de uma tarea hermenêutica que sea capaz de aplicarlos a los casos concretos de forma justificada y razonable, dotándolos de esa manera de contenidos normativos concretos (...) Decisión del poder constituyente lo que em realidade es uma decisión más o menos libre del próprio juzgador."

${ }^{9}$ STRECK, Lênio. Hermenêutica, Constituição, Autonomia do Direito e o Direito Fundamental a obter respostas adequadas (corretas). In Intepretação Constitucional. Reflexões sobre (a nova hermenêutica). Salvador: Edições JusPodivm, 2010, p. 244.
} 
AMORIM, Camila Silva de. Efetividade das normas constitucionais e sentenças com efeitos aditivos na justiça constitucional portuguesa e brasileira. Revista Eletrônica Direito e Política, Programa de Pós-Graduação Stricto Sensu em Ciência Jurídica da UNIVALI, Itajaí, v.10, n.2, $1^{0}$ quadrimestre de 2015. Disponível em: www.univali.br/direitoepolitica - ISSN 1980-7791.

\subsection{Eficácia e efetividade das normas constitucionais}

Tradicionalmente, a doutrina analisa os atos jurídicos em geral, e os atos normativos em particular, em três planos distintos: o da existência (ou vigência), o da validade e o da eficácia.

A vigência (do verbo viger, do latim vigere) no seu sentido técnico-formal de norma que foi regularmente promulgada e publicada, com a condição de entrar em vigor em data determinada, qualidade da norma que a faz existir juridicamente. ${ }^{10}$

A teoria jurídica conhece a vacatio legis, que é o período que vai da publicação do ato promulgatório até a efetiva entrada da lei em vigor, durante esse período continuam em vigor a norma anterior, no caso da constituição, tem-se a vacatio constitucionais, até a promulgação da nova constituição a antiga permanece em vigor. ${ }^{11}$

A validade da norma está relacionada à sua legitimidade. É sabido que as normas ordinárias são legítimas quando se conformam material e substancialmente com os ditames da Constituição (compatibilidade vertical), as normas jurídicas contrarias à Constituição são ilegítimas, inválidas, inconstitucionais e ineficazes juridicamente, em princípio. Já a validade da norma constitucional está intimamente relacionada ao conceito de Constituição. ${ }^{12}$

De acordo com José Joaquim Gomes Canotilho, a validade da Constituição se desenvolve dentro da ideia de Constituição aberta, onde:

relativiza-se a função material da constituição e justifica-se a 'desconstitucionalização' de elementos substantivadores da ordem constitucional (...). Está terá de ordenar o processo da vida política fixando limites às tarefas do Estado e recortando dimensões prospectivas traduzidas na formulação

\footnotetext{
10 SILVA, José Afonso da. Aplicabilidade das normas constitucionais. 7 ed. São Paulo: Malheiros, 2007, p. 52.

11 SILVA, José Afonso da. Aplicabilidade das normas constitucionais. 7 ed. São Paulo: Malheiros, 2007, p. 53.

12 SILVA, José Afonso da. Aplicabilidade das normas constitucionais. 7 ed. São Paulo: Malheiros, 2007, p. 55-56.
} 
AMORIM, Camila Silva de. Efetividade das normas constitucionais e sentenças com efeitos aditivos na justiça constitucional portuguesa e brasileira. Revista Eletrônica Direito e Política, Programa de Pós-Graduação Stricto Sensu em Ciência Jurídica da UNIVALI, Itajaí, v.10, n.2, $1^{\circ}$ quadrimestre de 2015. Disponível em: www.univali.br/direitoepolitica - ISSN 1980-7791.

dos fins sociais mais significativos e na identificação de alguns programas da conformação constitucional. ${ }^{13}$

Entende-se que uma Constituição é válida quando representa os ideais e interesses de um povo, de uma nação com seus costumes, história e tradições, para além dos fatores reais de poder, mais que uma norma fundamental e vontade política, é a soma de direitos fundamentais universalmente reconhecidos à expressão de soberania do povo.

Quanto à eficácia da norma constitucional, como a norma se manifesta, diversas são as classificações, destaca-se a norte-americana, a italiana e a brasileira do doutrinador José Afonso da Silva, com a classifiação histórica em normas constitucionais de eficácia plena, contida e limitada.

Para o direito americano as normas constitucionais, do ponto de vista da sua aplicabilidade podem ser self-executing provisions e not self-executing provisions. ${ }^{14}$

A Constitutional provision may be said to be self-executing if it supplies a suficiente rule by means of which the right given may be enjoyed and protected, or the duty imposed may enforced, and it is not-executing when it merely indicates principles, without laying down rules by means of which those principles may be given the force of law. ${ }^{15}$

A classificação norte-americana não explica satisfatoriamente a eficácia e a aplicabilidade de normas consideradas programáticas, razão que fez a doutrina italiana a refletir sobre o tema, apresentando normas diretivas ou programáticas; normas preceptivas, obrigatórias e de aplicabilidade imediata; normas preceptivas, obrigatórias, mas não de aplicabilidade imediata. ${ }^{16}$

13 CANOTILHO, J. J. Gomes. Direito Constitucional e Teoria da Constituição. Edições Almedina. Coimbra, 7. ed. 2003, p. 1339.

${ }^{14}$ COOLEY, Thomas M. Treatise on the constitucional limitations. 7 ed. Boston, Brown and Co, 1890, p. 119.

${ }^{15}$ COOLEY, Thomas M. Treatise on the constitucional limitations. 7 ed. Boston, Brown and Co, $1890,119-123$.

16 SILVA, José Afonso da. Aplicabilidade das normas constitucionais. 7 ed. São Paulo: Malheiros, 2007, p. 80. 
AMORIM, Camila Silva de. Efetividade das normas constitucionais e sentenças com efeitos aditivos na justiça constitucional portuguesa e brasileira. Revista Eletrônica Direito e Política, Programa de Pós-Graduação Stricto Sensu em Ciência Jurídica da UNIVALI, Itajaí, v.10, n.2, $1^{0}$ quadrimestre de 2015. Disponível em: www.univali.br/direitoepolitica - ISSN 1980-7791.

As diretivas refletem diretivas ao legislador futuro, as normas preceptivas obrigatórias contêm comandos jurídicos de aplicação direta e imediata, invalidam as leis discordantes e, por fim, as normas preceptivas, obrigatórias, mas não de aplicabilidade imediata, necessitam de normas jurídicas integrativas. ${ }^{17}$

José Afonso da Silva critica essa classificação porque as normas programáticas se dirigem só ao legislador, todas as normas constitucionais são jurídicas dotadas de imperatividade, mesmo que permissivas e normas puramente diretivas não existem no direito contemporâneo. ${ }^{18}$

De acordo com José Afonso da Silva, as normas constitucionais podem ter eficácia plena, contida e limitada. Sua teoria foi um marco à teoria da aplicabilidade das normas constitucionais, onde desenvolveu a teoria tricotômica do italiano Vezio Crisafulli.

Normas constitucionais de eficácia plena seriam as que já receberam do constituinte normatividade suficiente à sua incidência imediata, não necessitam de providência normativa ulterior a sua aplicação, desde logo exigíveis e por isso sua aplicabilidade é direta, imediata e integral. ${ }^{19}$

São normas que contenham vedações ou proibições; confiram isenções, imunidades e prerrogativas, não designem órgãos ou autoridades especiais a que incumbam especificamente sua execução, não indiquem processos especiais de sua execução, não exijam a elaboração de novas normas legislativas que Ihes completem o alcance e o sentido, ou lhes fixem o conteúdo, por que já se apresentam suficientemente explícitas. ${ }^{20}$

As normas constitucionais de eficácia contida ou prospectiva têm aplicabilidade direta e imediata, mas possivelmente não integral. Isso porque a norma

17 SILVA, José Afonso da. Aplicabilidade das normas constitucionais. 7 ed. São Paulo: Malheiros, 2007, p. 80.

18 SILVA, José Afonso da. Aplicabilidade das normas constitucionais. 7 ed. São Paulo: Malheiros, 2007, p. 81.

19 SILVA, José Afonso da. Aplicabilidade das normas constitucionais. 7 ed. São Paulo: Malheiros, 2007, p. 101.

${ }^{20}$ SILVA, José Afonso da. Aplicabilidade das normas constitucionais. 7 ed. São Paulo: Malheiros, 2007, p. 101. 
AMORIM, Camila Silva de. Efetividade das normas constitucionais e sentenças com efeitos aditivos na justiça constitucional portuguesa e brasileira. Revista Eletrônica Direito e Política, Programa de Pós-Graduação Stricto Sensu em Ciência Jurídica da UNIVALI, Itajaí, v.10, n.2, $1^{0}$ quadrimestre de 2015. Disponível em: www.univali.br/direitoepolitica - ISSN 1980-7791.

infraconstitucional poderá reduzir sua abrangência ou até mesmo motivo de ordem pública, bons costumes e paz social. Como por exemplo, a decretação do estado de defesa ou de sítio. ${ }^{21}$

Normalmente, acompanhada das expressões: "fixada em lei", "que a lei estabelecer" e "na forma da lei". Denominadas por Michel Temer de normas de "eficácia redutível" ou "restringível". ${ }^{22}$

E as normas constitucionais de eficácia limitada são aquelas que no momento da promulgação da Constituição não têm o condão de produzir todos os seus efeitos e por isso sua aplicabilidade é mediata e reduzida ou diferida. ${ }^{23}$ Segundo Vezio Crisafulli, produzem um mínimo efeito de vinculação do legislador aos seus vetores. $^{24}$

Para José Afonso da Silva, tais normas têm eficácia jurídica mediata, direta e vinculante, pois,

estabelecem um dever para o legislador ordinário; condicionam a legislação futura, com a consequência de serem inconstitucionais as leis $e$ atos que as ferirem; informam a concepção do estado e da sociedade e inspiram a sua ordenação jurídica, mediante a atribuição de fins sociais, proteção dos valores de justiça e revelação dos componentes do bem comum; constituem sentido teleológico para interpretação, integração e aplicação das normas jurídicas; condicionam a atividade discricionária da Administração e do Judiciário; criam situação jurídicas subjetivas de vantagem e desvantagem. ${ }^{25}$

As normas de eficácia limitada subdividem-se em normas de eficácia limitada declaratórias de princípios institutivos ou organizativos (ou orgânicos) que contêm esquemas gerais de estruturação de órgãos e entidades, impositivas ou

${ }^{21}$ LENZA, Pedro. Direito Constitucional Esquematizado. 13. ed. atual e ampl. São Paulo: Saraiva, 2009, p. 136-137.

22 TEMER, Michel. Elementos de um direito constitucional. 10. ed. São Paulo: 1993, p. 116.

${ }^{23}$ LENZA, Pedro. Direito Constitucional Esquematizado. 13. ed. atual e ampl. São Paulo: Saraiva, 2009, p. 138.

${ }^{24}$ CRISAFULLI, Vezio. La Constituzione e le sue disposizioni di principio. Milão, Dott. A. Giuffrè Editore, 1952, p. 34-35.

${ }^{25}$ SILVA, José Afonso da. Aplicabilidade das normas constitucionais. 7 ed. São Paulo: Malheiros, 2007, p. 164. 
AMORIM, Camila Silva de. Efetividade das normas constitucionais e sentenças com efeitos aditivos na justiça constitucional portuguesa e brasileira. Revista Eletrônica Direito e Política, Programa de Pós-Graduação Stricto Sensu em Ciência Jurídica da UNIVALI, Itajaí, v.10, n.2, $1^{\circ}$ quadrimestre de 2015. Disponível em: www.univali.br/direitoepolitica - ISSN 1980-7791.

facultativas; e normas de eficácia limitada declaratórias de princípios programáticos, que veiculam programas a serem implementados pelo Estado. ${ }^{26}$

Crisafulli estudou as normas programáticas em vários ensaios conceituando-a como normas com as quais um programa de ação é assumido pelo Estado e assinalado aos seus órgãos, legislativos, de direção política e administrativa. ${ }^{27}$

Diz Vezio Crisafulli:

Infine, I'efficacia interpretativa spettane alle norme costituzionali programmatiche nei confronti del diritto vigente - prima della transformazione di questo nel senso dalle norme medesime determinato - permette a sua volta a chiunque vi abbia interesse di valersi degli abituali remidi giuridici contro atti administrativi vincolati e decisioni giurisdizionali dalle quali esulino elementi di discrezionalità, che, in concreto, non ne abbiamo tenuto conto nell'applicare ed interpretare ele vecchie norme di legge, da cui seguita ad essere regolata - in ipotesi - uma certa matéria: ciò che si que indiretamente, in un ulteriore pratico corretivo per il caso, che qui si esamina, di inerzia legislativa. ${ }^{28}$

É no campo das normas constitucionais de eficácia limitada onde se vislumbra maior espaço para atuação do poder judiciário, haja vista que sua aplicabilidade depende da atividade futura do legislador.

O que leva ao surgimento de instrumentos da eficácia constitucional como a inconstitucionalidade por omissão, assim como a iniciativa popular, e na legislação brasileira, o mandado de injunção, que serão examinados mais a frente.

Todavia, cumpre analisar um quarto plano, além dos mencionados planos da validade, existência e eficácia, que por muito tempo foi olvidado pela doutrina: o da efetividade ou eficácia social da norma.

\footnotetext{
${ }^{26}$ LENZA, Pedro. Direito Constitucional Esquematizado. 13. ed. atual e ampl. São Paulo: Saraiva, 2009, p. 139.

${ }^{27}$ CRISAFULLI, op. cit.. Mencionado autor distingue as normas programáticas em dois grupos: normas programáticas de simples escopo, que prescrevem aos meios estatais certos fins e normas programáticas que prescrevem o fim a atingir limitando a discricionariedade administrativa.
}

${ }^{28}$ Vezio. La Constituzione e le sue disposizioni di principio. Milão, Dott. A. Giuffrè Editore, 1952 , p. 34-35. 
AMORIM, Camila Silva de. Efetividade das normas constitucionais e sentenças com efeitos aditivos na justiça constitucional portuguesa e brasileira. Revista Eletrônica Direito e Política, Programa de Pós-Graduação Stricto Sensu em Ciência Jurídica da UNIVALI, Itajaí, v.10, n.2, 10 quadrimestre de 2015. Disponível em: www.univali.br/direitoepolitica - ISSN 1980-7791.

A eficácia social se verifica na potencialidade para regular determinadas relações da norma vigente ao caso concreto, ao passo que a eficácia jurídica está na norma apta a produzir efeito em situações concretas onde sua simples edição já produz o efeito jurídico de revogar as normas anteriores. ${ }^{29}$

A ideia de efetividade expressa o cumprimento da norma o fato de ela ser aplicada e observada, de uma conduta humana se verificar na conformidade de seu conteúdo, o desempenho concreto de sua função social. Ela representa a materialização, no mundo dos fatos, dos preceitos legais e simboliza a aproximação, tão intima quanto possível, entre o dever-ser normativo e o ser da realidade social. ${ }^{30}$

Uma Constituição, ao instituir o Estado, (a) organiza o exercício do poder político, (b) define direitos fundamentais ao povo e (c) estabelece determinados princípios e traça fins públicos a serem alcançados. Por via de consequência, as normas materialmente constitucionais podem ser agrupadas nas seguintes categorias: a) normas constitucionais de organização, b) normas constitucionais definidoras de direitos e c) normas constitucionais programáticas. ${ }^{31}$

A doutrina brasileira da efetividade das normas constitucionais tem nas normas constitucionais de organização a finalidade de estruturar e disciplinar o exercício do poder político. ${ }^{32}$

\footnotetext{
29 TEMER, Michel. Elementos de um direito constitucional. 10. ed. São Paulo: 1993, p. 25.

30 BARROSO, Luís Roberto. O direito constitucional e a efetividade de suas normas. Limites e possibilidades da Constituição brasileira. 7. ed. Rio de Janeiro: Renovar, 2003, p. 85.

31 BARROSO, Luís Roberto. A doutrina brasileira da efetividade. Constituição e democracia: estudos em homenagem ao professor J. J. Gomes Canotilho. São Paulo: Malheiros, 2006, p. 435-448.

32 BARROSO, Luís Roberto. A doutrina brasileira da efetividade. Constituição e democracia: estudos em homenagem ao professor J. J. Gomes Canotilho. São Paulo: Malheiros, 2006, p. 435-448. Para tal fim: CONSTITUÇÃO DA REPÚBLICA FEDERATIVA DO BRASIL DE 1988 "(i) veiculam as decisões políticas fundamentais (arts. 10, $2^{\circ}$ e 76), (ii) definem as competências dos órgãos (arts. 49, 84, 96) e das entidades estatais (arts. 21, 25, § 10, 30); (iii) criam órgãos públicos (arts. 44, 92), autorizam sua criação (art. 125, § $3^{\circ}$ ), traçam regras à sua composição (art. 101) e ao seu funcionamento (art. 44, parágrafo único); e (iv) estabelecem normas processuais ou procedimentais: de revisão da própria Constituição (art. 60), de defesa da Constituição (art. 102, I, "a" e 103), de elaboração legislativa (art. 47), de fiscalização (arts. 71, II, 50). As normas de organização dirigem, na generalidade dos casos, aos próprios Poderes de Estado e seus agentes, o que não significa, todavia, que não possam repercutir na esfera jurídica dos indivíduos".
} 
AMORIM, Camila Silva de. Efetividade das normas constitucionais e sentenças com efeitos aditivos na justiça constitucional portuguesa e brasileira. Revista Eletrônica Direito e Política, Programa de Pós-Graduação Stricto Sensu em Ciência Jurídica da UNIVALI, Itajaí, v.10, n.2, 10 quadrimestre de 2015. Disponível em: www.univali.br/direitoepolitica - ISSN 1980-7791.

As normas constitucionais definidoras de direitos são as que "tipicamente geram direitos subjetivos, investindo o jurisdicionado no poder de exigir do Estado - ou de outro eventual destinatário da norma - prestações positivas ou negativas, que proporcionem o desfrute dos bens jurídicos nela consagrados". Seriam os direitos individuais, políticos, sociais e difusos. ${ }^{33}$

Não é diferente na Constituição da República Portuguesa, onde também há normas constitucionais de aplicabilidade direta de organização e definidoras de direitos e normas de conteúdo programático. Por exemplo: artigos $5^{\circ}$ e $6^{\circ}-12^{\circ}$ a $230-370$, 7; entre outros.

Notadamente, são nas normas programáticas que se encontra questão atinente ao tema em análise normas-fim que justificam a necessidade de intervenção dos órgãos legiferantes.

Segundo J.J.G. Canotilho, a positividade jurídico-constitucional das normas programáticas significa fundamentadamente: (1) vinculação do legislador, de forma permanente a sua realização; (2) vinculação positiva de todos os órgãos concretizadores (directivas materiais permanentes); (3) vinculação na qualidade de limites materiais negativos, dos poderes públicos, justificando a eventual censura, sob forma de inconstitucionalidade, em relação aos atos que a contrariem. 34

\subsection{Normas constitucionais e jurisdição constitucional}

A constitucionalização do Direito importou um pós-positivismo, com a modificação de paradigmas, na medida em que o reconhecimento da força

33 BARROSO, Luís Roberto. A doutrina brasileira da efetividade. Constituição e democracia: estudos em homenagem ao professor J. J. Gomes Canotilho. Complementa o autor que: "As normas constitucionais programáticas veiculam princípios, desde logo observáveis, ou traçam fins sociais a serem alcançados pela atuação futura dos poderes públicos. Não geram direitos subjetivos na sua versão positiva, mas geram na sua feição negativa. São dessa categoria as regras que preconizam a função social da propriedade (art. 170, III), a redução das desigualdades regionais (art. 170, VII) o apoio à cultura (art. 215), o fomento as práticas desportivas (art. 217), 0 incentivo à pesquisa (art. 218), dentre outras". Artigos da CF/88.

34 CANOTILho, J. J. Gomes. Direito Constitucional e Teoria da Constituição. Edições Almedina. Coimbra, 7. ed. 2003, p. 1177. 
AMORIM, Camila Silva de. Efetividade das normas constitucionais e sentenças com efeitos aditivos na justiça constitucional portuguesa e brasileira. Revista Eletrônica Direito e Política, Programa de Pós-Graduação Stricto Sensu em Ciência Jurídica da UNIVALI, Itajaí, v.10, n.2, $1^{0}$ quadrimestre de 2015. Disponível em: www.univali.br/direitoepolitica - ISSN 1980-7791.

normativa da Constituição muito bem analisada por Konrad Hesse trouxe novos contornos à questão da efetividade das normas constitucionais. E com este movimento acabou por se expandir a conhecida jurisdição constitucional, com a elaboração de novos parâmetros hermenêuticos sobre os direitos postos na Carta Magna. ${ }^{35}$

Com a Constituição de 1976, a jurisdição constitucional em Portugal tem um órgão contencioso de normas jurídicas que recebe competências do Conselho, da Comissão Constitucional e, relativamente a atos respeitantes às regiões autônomas (Lei n. 15/79), do Supremo Tribunal Administrativo e do Supremo Tribunal de Justiça, o Tribunal Constitucional. ${ }^{36}$

O Tribunal Constitucional exerce sua jurisdição no âmbito de toda ordem jurídica portuguesa e tem sede em Lisboa, sendo dotado de autonomia administrativa e dispondo de orçamento próprio (artigo 221 da Constituição da República Portuguesa).

Composto por 13 juízes em duas seções não especializadas e de igual hierarquia, constituídas por mais seis juízes. Haverá composição plenária para fiscalização abstrata de constitucionalidade. Dez dos magistrados são escolhidos pela Assembleia da República e três por cooptação pelo próprio Tribunal para exercerem mandatos de nove anos sem renovação (artigos 222 a 224 da Constituição da República Portuguesa).

Gozam das garantias de independência, inamovibilidade, imparcialidade e irresponsabilidade e estão sujeitos as mesmas incompatibilidades dos juízes dos demais tribunais.

Nos dizeres de Nadais, Vitorino e Canas: o Tribunal Constitucional "é, em nosso país, o meio mais idôneo de assegurar o cumprimento do programa

\footnotetext{
${ }^{35}$ KIM, Richard Pae. Neoconstitucionalismo: hermenêutica constitucional e atividade jurisdicional na tutela dos direitos do cidadão. In Revista Ajuris. Associação dos Juízes do Rio Grande do Sul. V. 36. N. 116, p. 269-290. Dezembro 2009.
}

${ }^{36}$ MORAES, Alexandre. Jurisdição Constitucional e tribunais constitucionais. Garantia Suprema da Constituição. 2. ed. São Paulo: Atlas, 2003, p. 178-180. 
AMORIM, Camila Silva de. Efetividade das normas constitucionais e sentenças com efeitos aditivos na justiça constitucional portuguesa e brasileira. Revista Eletrônica Direito e Política, Programa de Pós-Graduação Stricto Sensu em Ciência Jurídica da UNIVALI, Itajaí, v.10, n.2, $1^{\circ}$ quadrimestre de 2015. Disponível em: www.univali.br/direitoepolitica - ISSN 1980-7791.

constitucional. O Tribunal Constitucional é o guardião da Constituição. O Tribunal Constitucional controla designadamente a atividade do legislador."37

No caso brasileiro, a Constituição da República Federativa do Brasil de 1988 ampliou a jurisdição constitucional do Supremo Tribunal Federal, responsável pelo controle de constitucionalidade, inclusive por omissão, pela ação declaratória de constitucionalidade e pela arguição de descumprimento de preceito fundamental.

O Supremo Tribunal Federal é órgão do poder judiciário, autônomo e independente, tendo sede na Capital Federal, Brasília. Com autonomia administrativa e com poder para elaborar suas propostas orçamentárias. Órgão máximo não subordinado a nenhum outro órgão estatal devendo obediência a Constituição Federal (artigo 92 e seguintes da Constituição).

Composto por 11 membros, divididos em duas Turmas que se encontram em mesmo nível hierárquico, com cinco membros cada uma, uma vez que seu Presidente só participa em sessões plenárias. Possuem vitaliciedade no cargo, nomeados livremente pelo Presidente da República após aprovação absoluta da maioria dos membros do Senado Federal (artigo 101 CF/88 e Regimento interno do STF).

A Constituição em seu artigo 12, $3^{\circ}$, IV, exige que os membros do Supremo Tribunal Federal sejam brasileiros natos, no gozo dos direitos políticos, de notável saber jurídico e reputação ilibada. Com idade superior a 35 e inferior a 65 anos. Com as mesmas garantias dos demais membros do judiciário. E incompatibilidades com o cargo estão no artigo 95 da Constituição. ${ }^{38}$ Não há uma lei orgânica do Supremo Tribunal Federal como no sistema português. Serão

37 NADAIS, Antônio, VITORINO, Antônio, CANAS, Vitalino. Lei sobre organização, funcionamento e processo no tribunal constitucional. Lisboa: AAEDL, 1984, p. 38.

38 BRASIL. CF/88. Art. 95. Os juízes gozam das seguintes garantias: I - vitaliciedade, que, no primeiro grau, só será adquirida após dois anos de exercício, dependendo a perda do cargo, nesse período, de deliberação do tribunal a que o juiz estiver vinculado, e, nos demais casos, de sentença judicial transitada em julgado; II - inamovibilidade, salvo por motivo de interesse público, na forma do art. 93, VIII; III - irredutibilidade de subsídio, ressalvado o disposto nos arts. 37, X e XI, 39, § $40,150, I I, 153, I I I$, e 153, \& 20, I. 
AMORIM, Camila Silva de. Efetividade das normas constitucionais e sentenças com efeitos aditivos na justiça constitucional portuguesa e brasileira. Revista Eletrônica Direito e Política, Programa de Pós-Graduação Stricto Sensu em Ciência Jurídica da UNIVALI, Itajaí, v.10, n.2, $1^{0}$ quadrimestre de 2015. Disponível em: www.univali.br/direitoepolitica - ISSN 1980-7791.

julgados pelo Senado Federal por crimes de responsabilidade e nos demais casos pelo próprio Supremo Tribunal Federal (artigos 52, II e 102, "b" da CF/88).

As competências do Supremo Tribunal Federal estão estabelecidas no artigo 102 da Constituição e destaca-se o controle de constitucionalidade das normas constitucionais.

\section{OMISSÃO LEGISLATIVA E ASCENSÃO DO JUDICIÁRIO}

\subsection{Omissão normativa inconstitucional e responsabilidade do Estado}

"A inconstitucionalidade por omissão, como fenômeno jurídico novo tem desafiado a criatividade da doutrina, da jurisprudência e dos legisladores, é a que se refere à inércia na elaboração de atos normativos necessários à realização dos comandos constitucionais". 39 Relaciona ao sussurrado problema da "síndrome de inefetividade das normas constitucionais".

Existe inconstitucionalidade por omissão quando um órgão público se abstém de editar um acto, cuja prática é exigida pela Constituição, pelo que a inércia do decisor viola um dever constitucional de agir. ${ }^{40}$

A necessidade de elaboração de lei para integrar a eficácia de um comando constitucional, seja em relação às normas constitucionais de organização, seja em relação às normas definidoras de direitos é condição sine qua non para exequibilidade da norma constitucional, e o legislador tem o dever de legislar. ${ }^{41}$

\footnotetext{
39 BARROSO, Luís Roberto. A doutrina brasileira da efetividade. Constituição e democracia: estudos em homenagem ao professor J. J. Gomes Canotilho. São Paulo: Malheiros, 2006, p. 435-448.

40 MORAIS, Carlos Blanco de. Justiça Constitucional. Tomo I: Garantia da Constituição e controlo da constitucionalidade. Coimbra: Coimbra Editora, 2002, p. 135.

${ }^{41}$ MIRANDA, Jorge. Manual de Direito Constitucional. Vol. VI, 3a ed. Coimbra, Coimbra Editora, 2008 , p. 320.
} 
AMORIM, Camila Silva de. Efetividade das normas constitucionais e sentenças com efeitos aditivos na justiça constitucional portuguesa e brasileira. Revista Eletrônica Direito e Política, Programa de Pós-Graduação Stricto Sensu em Ciência Jurídica da UNIVALI, Itajaí, v.10, n.2, $1^{0}$ quadrimestre de 2015. Disponível em: www.univali.br/direitoepolitica - ISSN 1980-7791.

Segundo Canotilho, a ordem de legislar é concreta, mas não permanente, no sentido de que se exaure assim que a norma é elaborada. ${ }^{42}$

A omissão distingue-se de uma mera lacuna, porque esta pode produzir-se involuntariamente, ao passo que aquela é necessariamente voluntária, já que existia a obrigação de fazer e não se fez. ${ }^{43}$

Corresponde ao descumprimento à obrigação de legislar, "uma infração constitucional", ${ }^{44}$ pode ser omissão total ou absoluta e parcial. Total quando o legislador não editou as leis necessárias para a viabilização do exercício de um direito, e, parcial quando não viabilizou por completo o comando constitucional. ${ }^{45}$

Para Jorge Pereira da Silva, o controle da omissão legislativa reúne um elemento material (inércia do legislador), um formal (violação de um dever de atuação legislativa) e um fático (real possibilidade do legislador de atuar). Gerando não só a declaração da omissão em controle de constitucionalidade como também a responsabilização civil do legislador. ${ }^{46}$

Além das omissões legislativas atinentes a falta da elaboração da norma, há também omissões pela falta de adoção de medidas políticas e administrativas ${ }^{47}$, e, no plano internacional, relacionadas à demora na ratificação de um tratado, ou, a falta de transposição de uma diretiva para o ordenamento nacional. Mas esse trabalho está direcionado às omissões legislativas de normas constitucionais.

\footnotetext{
42 CANOTILHO, J. J. Gomes. Direito Constitucional e Teoria da Constituição. Edições Almedina. Coimbra, 7. ed. 2003, p. 1177.

43 RUIZ, Mortati Maria Ángeles Ahumada, El control de constitucionalidade de las omisiones legislativas, in Revista del Centro de Estudios Constitucionales, vol. 8, Madri, Centro de Estudios Constitucionales, p. 170-174, jan.-abr. 1991.

44 MENÉNDEZ, Ignacio Villaverde. La inconstitucionalidade por omisión de los silêncios legislativos, in Anuario de Derecho Constitucional y Parlamentario, no 8, 1996, p. 3961-3999.

${ }^{45}$ MENDES, Gilmar Ferreira. Jurisdição Constitucional no Brasil: o problema da omissão legislativa inconstitucional. Disponível em: www.portaldeperiodicos.idp.edu.br, acesso em 20 de janeiro de 2012.

${ }^{46}$ SILVA, Jorge Pereira. Dever de legislar e Protecção Jurisdicional contra Omissões Legislativas. Lisboa, Universidade Católica, 2003, p. 13, 89-90.

47 CLÈVE, Clèmerson Merlin. A fiscalização abstrata da constitucionalidade no direito brasileiro. 2 ed. rev. atual e ampl. São Paulo: RT, 2000, p. 322.
} 
AMORIM, Camila Silva de. Efetividade das normas constitucionais e sentenças com efeitos aditivos na justiça constitucional portuguesa e brasileira. Revista Eletrônica Direito e Política, Programa de Pós-Graduação Stricto Sensu em Ciência Jurídica da UNIVALI, Itajaí, v.10, n.2, 10 quadrimestre de 2015. Disponível em: www.univali.br/direitoepolitica - ISSN 1980-7791.

A Constituição da República Portuguesa prevê a inconstitucionalidade por omissão em seu artigo 283, 1 e $2^{48}$, por via principal e prescreve medidas ou diretrizes necessárias, uma espécie de apelo ao impulso legiferante, como forma de equilíbrio entre os princípios da garantia da Constituição e democrático. ${ }^{49}$

A Constituição Brasileira de 1988, inspirada na Constituição Portuguesa 50 introduziu a inconstitucionalidade por omissão para o controle por via principal e criou o mandado de injunção para tutela incidental e in concreto.

No caso brasileiro foram criados a partir do patamar do constitucionalismo brasileiro da efetividade quando ganhou impulso os estudos acerca do neoconstitucionalismo e da teoria dos direitos fundamentais. ${ }^{51}$

É neste cenário que se insere o fenômeno da inconstitucionalidade por omissão que, como colocado, está relacionado com o desafio da efetividade constitucional, preocupação inerente à ordem jurídica do modelo social e à própria realização de uma Constituição Dirigente. ${ }^{52}$

Ademais, o controle de constitucionalidade por omissão está previsto no capítulo dos direitos fundamentais da Carta Maior Brasileira. E de forma genérica no artigo 18 da Constituição da República Portuguesa de $1976 .^{53}$

\footnotetext{
${ }^{48}$ CRP/76, Art. 283. 1. A requerimento do Presidente da República, do Provedor de Justiça ou, com fundamento em violação de direitos das regiões autónomas, dos presidentes das Assembleias Legislativas das regiões autónomas, o Tribunal Constitucional aprecia e verifica o não cumprimento da Constituição por omissão das medidas legislativas necessárias para tornar exequíveis as normas constitucionais. 2. Quando o Tribunal Constitucional verificar a existência de inconstitucionalidade por omissão, dará disso conhecimento ao órgão legislativo competente.

49 MIRANDA, Jorge. Manual de Direito Constitucional. Vol. VI, $3^{a}$ ed. Coimbra, Coimbra Editora, 2008 , p. 316.

50 PIOVESAN, Flávia. Proteção judicial contra omissões legislativas: ação direta de inconstitucionalidade por omissão e mandado de injunção. 2 ed. rev., atual e ampl. São Paulo: Editora Revista dos Tribunais, 2003, p. 103. Vide BONAVIDES, Paulo. Curso de direito constitucional. 4. ed., São Paulo: 1993, p. 261.

51 BARROSO, Luís Roberto. A doutrina brasileira da efetividade. Constituição e democracia: estudos em homenagem ao professor J. J. Gomes Canotilho. São Paulo: Malheiros, 2006, p. 435-448.

52 PIOVESAN, Flávia. Proteção judicial contra omissões legislativas: ação direta de inconstitucionalidade por omissão e mandado de injunção. 2 ed. rev., atual e ampl. São Paulo: Editora Revista dos Tribunais, 2003, p. 103.

$53 \mathrm{CRP} / 76$. Art. 18. Os preceitos constitucionais respeitantes aos direitos, liberdades e garantias são diretamente aplicáveis as entidades públicas e privadas.
} 
AMORIM, Camila Silva de. Efetividade das normas constitucionais e sentenças com efeitos aditivos na justiça constitucional portuguesa e brasileira. Revista Eletrônica Direito e Política, Programa de Pós-Graduação Stricto Sensu em Ciência Jurídica da UNIVALI, Itajaí, v.10, n.2, 10 quadrimestre de 2015. Disponível em: www.univali.br/direitoepolitica - ISSN 1980-7791.

Tanto na Constituição Portuguesa como na Brasileira a ação direta de inconstitucionalidade por omissão importará na declaração da inconstitucionalidade por omissão e na ciência ao órgão competente para que adote as providências necessárias para tornar exequíveis as normas constitucionais. Trata-se de uma decisão meramente declarativa. Controle concentrado em um único órgão jurisdicional, o Tribunal Constitucional em Portugal e o Supremo Tribunal Federal no Brasil. ${ }^{54}$

Diferem na legitimidade ativa para propor a ação, na carta portuguesa apenas o Presidente da República, o Provedor de Justiça ou com fundamento em violação de direitos das regiões autônomas, os Presidentes das Assembleias Legislativas regionais; na Constituição brasileira o rol de legitimados é mais extenso. ${ }^{55}$

E ainda, no pólo passivo da ação no Brasil está o legislador ou órgão administrativo omisso, em Portugal, não fiscalização por omissão de atos não legislativos (atos políticos). ${ }^{56}$

Por fim, resta esboçar umas breves palavras acerca do instrumento tupiniquim, o mandado de injunção, considerado uma garantia constitucional, assim previsto no artigo 50, LXXI, "conceder-se-á mandado de injunção sempre que a falta da norma regulamentadora torne inviável o exercício dos direitos e liberdades constitucionais e das prerrogativas inerentes à nacionalidade, à soberania e à cidadania".

A legitimidade ativa deste remédio constitucional é de toda e qualquer pessoa, inclusive por entes coletivos, na defesa de direito subjetivo, cuja eficácia é inter

54 PIOVESAN, Flávia. Proteção judicial contra omissões legislativas: ação direta de inconstitucionalidade por omissão e mandado de injunção. 2 ed. rev., atual e ampl. São Paulo: Editora Revista dos Tribunais, 2003, p. 132.

55 BRASIL. CF/88. Art. 103. Podem propor a ação direta de inconstitucionalidade e a ação declaratória de constitucionalidade: I - o Presidente da República; II - a Mesa do Senado Federal; III - a Mesa da Câmara dos Deputados; IV - a Mesa de Assembléia Legislativa ou da Câmara Legislativa do Distrito Federal; V - o Governador de Estado ou do Distrito Federal; VI - o Procurador-Geral da República; VII - o Conselho Federal da Ordem dos Advogados do Brasil; VIII partido político com representação no Congresso Nacional; IX - confederação sindical ou entidade de classe de âmbito nacional.

56 PIOVESAN, Flávia. Proteção judicial contra omissões legislativas: ação direta de inconstitucionalidade por omissão e mandado de injunção. 2 ed. rev., atual e ampl. São Paulo: Editora Revista dos Tribunais, 2003, p. 133. 
AMORIM, Camila Silva de. Efetividade das normas constitucionais e sentenças com efeitos aditivos na justiça constitucional portuguesa e brasileira. Revista Eletrônica Direito e Política, Programa de Pós-Graduação Stricto Sensu em Ciência Jurídica da UNIVALI, Itajaí, v.10, n.2, 10 quadrimestre de 2015. Disponível em: www.univali.br/direitoepolitica - ISSN 1980-7791.

partes e a legitimidade passiva recai sobre um ente público, conforme entendimento do Supremo Tribunal Federal. ${ }^{57}$

Quanto aos efeitos da decisão concessiva do mandado de injunção há, assim como no controle de constitucionalidade por omissão, três correntes doutrinárias, a primeira (concretista) diz que cabe ao judiciário elaborar a norma regulamentadora faltante, a segunda (intermediária ou mandamental) em que o judiciário declara a inconstitucionalidade por omissão para que o órgão competente adote as providências necessárias para elaboração da norma e a terceira (não concretista), entende que o poder judiciário deve tornar viável, no caso concreto, o exercício do direito, liberdade ou prerrogativa. ${ }^{58}$

Na primeira hipótese tem-se o caso de ação de inconstitucionalidade por omissão junto à atuação do legislador; na segunda, tem-se uma ação de inconstitucionalidade por omissão propriamente dita. Logo, a terceira é a mais aceita, pois cabe ao judiciário a decisão saneadora da omissão para que se concretize o exercício do direito subjetivo constitucional. ${ }^{59}$ Embora haja uma tendência ao ativismo judicial em mandado de injunção. ${ }^{60}$

Resta mencionar que a responsabilidade do Estado diante das omissões normativas, em Portugal, há a responsabilização civil do legislador omisso, com

\footnotetext{
57 BRASIL. Mandados de injunção: MI 361-1-RJ, MI 20-4-DF, MI 323-8-DF.

58 LENZA, Pedro. Direito Constitucional Esquematizado. 13. ed. atual e ampl. São Paulo: Saraiva, 2009, p. 741.

59 PIOVESAN, Flávia. Proteção judicial contra omissões legislativas: ação direta de inconstitucionalidade por omissão e mandado de injunção. 2 ed. rev., atual e ampl. São Paulo: Editora Revista dos Tribunais, 2003, p. 148-165.

60 BRASIL. Mandado de Injunção. MI 758-DF/STF. Transcreve-se ementa do acórdão do MI 721 DF/STF. "Mandado de injunção - natureza. Conforme disposto no inciso LXXI do artigo 50 da Constituição Federal, conceder-se-á mandado de injunção quando necessário ao exercício dos direitos e liberdades constitucionais e das prerrogativas inerentes à nacionalidade, à soberania e à cidadania. Há ação mandamental e não simplesmente declaratória de omissão. A carga de declaração não é objeto da impetração, mas premissa da ordem a ser formalizada. Mandado de injunção - decisão - balizas. Tratando-se de processo subjetivo, a decisão possui eficácia considerada a relação jurídica nele revelada. Aposentadoria - trabalho em condições especiais prejuízo à saúde do servidor - inexistência de lei complementar - artigo 40, $\S 40$, da constituição federal. Inexistente a disciplina específica da aposentadoria especial do servidor, impõe-se a adoção, via pronunciamento judicial, daquela própria aos trabalhadores em geral - artigo 57, $\S 10$, da Lei no 8.213/91."
} 
AMORIM, Camila Silva de. Efetividade das normas constitucionais e sentenças com efeitos aditivos na justiça constitucional portuguesa e brasileira. Revista Eletrônica Direito e Política, Programa de Pós-Graduação Stricto Sensu em Ciência Jurídica da UNIVALI, Itajaí, v.10, n.2, ${ }^{\circ}$ quadrimestre de 2015. Disponível em: www.univali.br/direitoepolitica - ISSN 1980-7791.

forma de compensar o dano sofrido pelo cidadão com a mora legislativa via indenização. ${ }^{61}$

No Brasil não há previsão de responsabilidade do legislador, apenas o controle de constitucionalidade que é uma maneira diversa de responsabilização do legislador, porque não há indenização e a consequente demonstração do dano.

\subsection{Ascensão do judiciário}

A discussão sobre o grande poder discricionário (e, portanto, político) que exerce o Juiz Constitucional nas questões atinentes a constitucionalidade tem suscitado grandes discussões na América e na Europa sobre o alcance da justiça constitucional, que nos Estados Unidos se verbaliza com a expressão, cunhada por Alexander Bickel, da dificuldade contra majoritária. ${ }^{62}$

Ao retirar do plano de eficácia uma norma inconstitucional o judiciário atua como "legislador negativo"63 retirando do mundo jurídico tal norma, mas quando diante da omissão emite decisões de caráter normativo seu exercício hermenêutico é alargado e assume a postura do "legislador positivo".

\footnotetext{
${ }^{61}$ PORTUGAL. CONSTITUIÇÃO DA REPÚPLICA PORTUGUESA DE 1976 Art. 22. O Estado e as demais entidades públicas são civilmente responsáveis, em forma solidária com os titulares dos seus órgãos, funcionários ou agentes, por acções ou omissões praticadas no exercício das suas funções e por causa desse exercício, de que resulte violação dos direitos, liberdades e garantias ou prejuízo para outrem. Lei n. 67/2007. Art. 15 1. O Estado e as regiões autónomas são civilmente responsáveis pelos danos anormais causados aos direitos ou interesses legalmente protegidos dos cidadãos por actos que, no exercício da função político -legislativa, pratiquem, em desconformidade com a Constituição, o direito internacional, o direito comunitário ou acto legislativo de valor reforçado. 5. A constituição em responsabilidade fundada na omissão de providências legislativas necessárias para tornar exequíveis normas constitucionais depende da prévia verificação de inconstitucionalidade por omissão pelo Tribunal Constitucional.

62 BICKEL. Apud. ABELLÁN, Marina Gascón. Os limites da justiça constitucional: a invasão do âmbito político. Revista brasileira de estudos constitucionais-RBEC. ano 1. n. 1. jan./mar. 2007. Belo Horizonte: Fórum, p. 71-92, 2007. Vide A. Bickel, The Least Dangerous Branch: The Supreme Court at the Bar of Politics. Yale Univ. Press, New Haven, 1962.

${ }^{63}$ BRASIL. AÇÃO DIREITA DE CONSTITUCIONALIDADE. ADC 267/DF. Rel. Ministro Celso de Mello, DJ 19/05/95.
} 
AMORIM, Camila Silva de. Efetividade das normas constitucionais e sentenças com efeitos aditivos na justiça constitucional portuguesa e brasileira. Revista Eletrônica Direito e Política, Programa de Pós-Graduação Stricto Sensu em Ciência Jurídica da UNIVALI, Itajaí, v.10, n.2, $1^{0}$ quadrimestre de 2015. Disponível em: www.univali.br/direitoepolitica - ISSN 1980-7791.

Em Portugal não há espaço para a figura do legislador positivo como há no Brasil, onde o ativismo judicial é muito mais presente, sobretudo nas omissões legislativas.

E mais, em várias situações o legislador português parece ter levado em conta as decisões do Tribunal Constitucional, quer para legislar após as declarações de inconstitucionalidade por omissão, quer para prevenir esta mesma modalidade de ação. ${ }^{64}$

O grande problema em torno dessa ascensão do judiciário está no fato de representar uma quebra da tripartição dos poderes e uma afetação ao princípio democrático.

\section{SENTENÇAS INTERMÉDIAS E EFEITOS ADITIVOS VERSUS CONTROLE DE CONSTITUCIONALIDADE}

Nos Estados Democráticos de Direito existem dois sistemas de controle de constitucionalidade: o controle político e o controle jurisdicional. O controle jurisdicional se divide nos sistemas de controle difuso (modelo americano) e concentrado (modelo europeu).

O controle político é feito de forma preventiva quando da elaboração da norma pelo órgão legiferante, a exemplo da França. Já o controle jurisdicional é posterior, controle de constitucionalidade exercido incidentalmente pelos juízes e, por ação direta para discutir apenas a constitucionalidade da norma impugnada. ${ }^{65}$

Portugal e Brasil adotam um sistema híbrido que acolhe o modelo americano e o europeu.

\footnotetext{
${ }^{64}$ BRAGA, Valeschka e Silva. A omissão legislativa no Brasil e no Direito Comparado. Debates em Direito Público. In Revista de Direito dos Advogados da União, v. 4, n. 4, p. 99-118, out. 2005.

${ }^{65}$ LENZA, Pedro. Direito Constitucional Esquematizado. 13. ed. atual e ampl. São Paulo: Saraiva, 2009, p. 151-154.
} 
AMORIM, Camila Silva de. Efetividade das normas constitucionais e sentenças com efeitos aditivos na justiça constitucional portuguesa e brasileira. Revista Eletrônica Direito e Política, Programa de Pós-Graduação Stricto Sensu em Ciência Jurídica da UNIVALI, Itajaí, v.10, n.2, 10 quadrimestre de 2015. Disponível em: www.univali.br/direitoepolitica - ISSN 1980-7791.

Conforme examinado, é no controle de constitucionalidade por omissão que surgem as discussões a respeito das sentenças intermédias, que exigem a intepretação do juiz em caso de omissão legislativa. No caso português e no brasileiro é possível a modulação dos efeitos da sentença. ${ }^{66}$

Vale mencionar a tendência brasileira em dar maior efetividade e abrangência as decisões judiciais ao promover efeito vinculante às ações declaratórias de constitucionalidade e inconstitucionalidade (e a consequente reclamação), e ao criar o instituto das súmulas vinculantes (artigo 103-A CF/88 e Lei $\mathrm{n}$. 11.417/06). ${ }^{67} \mathrm{E}$ também, com a cláusula de manutenção do estado de fato: a da lei ainda constitucional, de força vinculativa rebus sic standibus, justificada pelo artigo $8^{\circ}, \S 1^{0}$ da Lei n. 9.868/99. ${ }^{68}$

\subsection{Sentenças intermédias e manipulativas}

Não há uma precisão terminológica, nem entendimento uníssono quanto às sentenças intermédias e manipulativas. Seguindo entendimento de Carlos Blanco de Moraes, ao Tribunal Constitucional incumbe o controle de constitucionalidade das leis, quando a ação de inconstitucionalidade é julgada procedente poderá ser classificada quanto aos seus efeitos em simples e manipulativa. ${ }^{69}$

\footnotetext{
66 Nas ações de inconstitucionalidade por ação e também por omissão no Brasil o artigo 27 da Lei n. 9.868/99 e o artigo 11 da Lei n. 9.882/99 trazem a possibilidade de modulação dos efeitos da declaração de inconstitucionalidade, cujos efeitos poderão ter eficácia a partir de determinado momento definido pelo julgador por razões de segurança jurídica ou excepcional interesse social, por maioria de dois terços dos membros do Supremo Tribunal Federal. A Lei n. 12.063/09 traz regras sobre a propositura da ação de inconstitucionalidade por omissão. E artigo 282, 3 e 4 da Constituição Portuguesa.

67 PELICIOLI, Angela Cristina. A sentença normativa na jurisdição constitucional. Disponível em: www2.senado.gov.br/bdsf/, Brasília a 44 n. 174 abr./jun. 2007. Acesso em 20 de janeiro de 2012.

68 ZAVASASCKI, Teori Albino. Eficácia das sentenças na jurisdição constitucional. São Paulo: Editora Revista dos Tribunais, 2001, p. 114-115. BRASIL. Lei n. 9.868/99. Art. 9o Vencidos os prazos do artigo anterior, o relator lançará o relatório, com cópia a todos os Ministros, e pedirá dia para julgamento. $\S 1^{\circ} \mathrm{Em}$ caso de necessidade de esclarecimento de matéria ou circunstância de fato ou de notória insuficiência das informações existentes nos autos, poderá o relator requisitar informações adicionais, designar perito ou comissão de peritos para que emita parecer sobre a questão, ou fixar data para, em audiência pública, ouvir depoimentos de pessoas com experiência e autoridade na matéria.
}

69 BLANCO, Carlos Blanco de. As sentenças intermédias na justiça constitucional. Lisboa: AAFDL, 2009, p. 363. 
AMORIM, Camila Silva de. Efetividade das normas constitucionais e sentenças com efeitos aditivos na justiça constitucional portuguesa e brasileira. Revista Eletrônica Direito e Política, Programa de Pós-Graduação Stricto Sensu em Ciência Jurídica da UNIVALI, Itajaí, v.10, n.2, 10 quadrimestre de 2015. Disponível em: www.univali.br/direitoepolitica - ISSN 1980-7791.

A decisão que considera a norma inconstitucional e a retira do mundo jurídico é o que tal autor denomina de efeito simples da ação de inconstitucionalidade, o efeito manipulativo ocorre quando a decisão altera o sentido da norma impugnada. Subdivide-se em: sentenças restritivas dos efeitos temporais da decisão de inconstitucionalidade, sentenças interpretativas de acolhimento ou condicionais e sentenças portadoras de efeitos aditivos. ${ }^{70}$

Para Marina Abellán, a luz do princípio de conservação das leis, as sentenças interpretativas ou intermédias são aquelas que não anulam o texto da lei na medida em que admita alguma interpretação conforme a Constituição. Conjugam-se assim a primazia da Constituição e a conservação das leis. ${ }^{71}$

Nessa álea, as sentenças interpretativas de acolhimento e de rejeição, de acordo com Maria Benedita Urbano, uma interpretação adequadora, não se verificando a manipulação do texto da norma. ${ }^{72}$

Porém, quando o Tribunal Constitucional escolhe a melhor interpretação dentre outras interpretações constitucionais, invade claramente as competências da jurisdição ordinária, pois deixa sem efeito a liberdade interpretativa que se atribui aos órgãos de jurisdição ordinária, levando em conta a força vinculante de suas sentenças, realiza uma tarefa quase legislativa. ${ }^{73}$

\footnotetext{
70 BLANCO, Carlos Blanco de. As sentenças intermédias na justiça constitucional. Lisboa: AAFDL, 2009, p. 363.

71 ABELLÁN, Marina Gascón. Os limites da justiça constitucional: a invasão do âmbito político. Revista brasileira de estudos constitucionais-RBEC. ano 1. n. 1. jan./mar. 2007. Belo Horizonte: Fórum, p. 71-92, 2007. Continua a autora, nas palavras do Tribunal Constitucional espanhol são sentenças interpretativas "aquelas que rejeitam uma demanda de inconstitucionalidade ou, a mesma coisa, declaram a constitucionalidade do preceito impugnado na medida em que se interprete no sentido (ou sentidos) que considera inadequados." STC 5/1981, 13 de fevereiro, fl. 6 .

72 URBANO, Maria Benedita Malaquias Pires. Sentenças intermédias: para além de Kelsen, mas ainda aquém de uma nova teoria da separação dos poderes. In livro de homenagem ao Doutor J. J. Gomes Canotilho. Vol. 3. Coimbra (no prelo).

73 ABELLÁN, Marina Gascón. Os limites da justiça constitucional: a invasão do âmbito político. Revista brasileira de estudos constitucionais-RBEC. ano 1. n. 1. jan./mar. 2007. Belo Horizonte: Fórum, p. 71-92, 2007
} 
AMORIM, Camila Silva de. Efetividade das normas constitucionais e sentenças com efeitos aditivos na justiça constitucional portuguesa e brasileira. Revista Eletrônica Direito e Política, Programa de Pós-Graduação Stricto Sensu em Ciência Jurídica da UNIVALI, Itajaí, v.10, n.2, $1^{0}$ quadrimestre de 2015. Disponível em: www.univali.br/direitoepolitica - ISSN 1980-7791.

Sendo assim, há uma linha tênue que separa a interpretação conforme a Constituição e a sentença de efeitos aditivos, por isso sentenças aditivas constitucionalmente obrigatórias (a rime obligate). ${ }^{74}$

Porém, conforme Canotilho, os limites da interpretação conforme a Constituição estão na letra e na clara vontade do legislador, devendo respeitar-se a economia da lei, não podendo haver a reconstrução de uma norma que não esteja explícita no texto. ${ }^{75}$

É nesse contexto que surgem as sentenças manipulativas (espécies de sentenças intermédias - interpretativas), o Tribunal Constitucional manipula a intepretação da lei, ultrapassa os limites da interpretação conforme (que são marcados pelas interpretações plausíveis da lei) para realizar uma simples alteração judicial do ordenamento invadindo o âmbito que a Constituição reserva ao legislador. ${ }^{76}$

Segundo Marina Abellán, em tais sentenças a interpretação que exclui uma intepretação e impõe outra recai sobre o programa normativo do preceito (sentenças substitutivas) ou sobre seu âmbito de aplicação, o reduzindo (sentenças redutoras) ou o ampliando (sentenças aditivas). ${ }^{77}$

La jurisprudência constitucional, simpre con la finalidade de evitar la rígida alternativa entre declaración de falta de fundamento o de inconstitucionalidad, ha elaborado, además, las denominadas sentencias manipulativas por las que la Corte procede a modificar o integrar las disposiciones sometidas a su enjuiciamento de um modo em que éstas salgan del juicio constitucional com un alcance normativo $y$ um contenido diferente al originário. Em el âmbito de las decisiones manipulativas deve añadirse uma ulterior consideración, la diferenciación entre decisiones aditivas y

74 ELIA, Leopoldo. Le sentenze additive e la piú recente giurisprudenza della Corte Costituzionale. In Scritti sulla giustizia costitucionale in onore di Vezio Crisafulli. Pádua. CEDAM; 1985, p. 307.

75 CANOTILHO, J. J. Gomes. Direito Constitucional e Teoria da Constituição. Edições Almedina. Coimbra, 7. ed. 2003, p. 1311.

76 ABELLÁN, Marina Gascón. Os limites da justiça constitucional: a invasão do âmbito político. Revista brasileira de estudos constitucionais-RBEC. ano 1. n. 1. jan./mar. 2007. Belo Horizonte: Fórum, p. 71-92, 2007.

77 ABELLÁN, Marina Gascón. Os limites da justiça constitucional: a invasão do âmbito político. Revista brasileira de estudos constitucionais-RBEC. ano 1. n. 1. jan./mar. 2007. Belo Horizonte: Fórum, p. 71-92, 2007. 
AMORIM, Camila Silva de. Efetividade das normas constitucionais e sentenças com efeitos aditivos na justiça constitucional portuguesa e brasileira. Revista Eletrônica Direito e Política, Programa de Pós-Graduação Stricto Sensu em Ciência Jurídica da UNIVALI, Itajaí, v.10, n.2, $1^{\circ}$ quadrimestre de 2015. Disponível em: www.univali.br/direitoepolitica - ISSN 1980-7791.

decisiones substutivas. Con las primeiras se hace referencia a aquel tipo de decisión com que la Corte declara inconstitucional una certa disposición por omitir algo (en la parte en la que no prevê); mientras que las segundas se caracterizan, em cambio, por el hecho de que con ellas la Corte declara la inconstitucionalid de una ley em la parte en la que prevê una determinada cosa y al no prever otra. ${ }^{78}$

O que tem sido reconhecido como sentenças manipulativas através das quais se considera que uma certa disposição é inconstitucional na parte em que prevê uma determinada coisa em vez de outra. Recurso comum na Itália no enquadramento penal de certos crimes, substituição da sanção penal por administrativa etc. ${ }^{79}$

O que se questiona é se o Tribunal Constitucional tem o poder de adicionar efeitos as suas decisões, o efeito aditivo das sentenças manipulativas por ele proferidas não seria uma afronta ao princípio da separação de poderes? Até que ponto o Tribunal Constitucional ao interpretar a norma pode adicionar efeitos a sua decisão?

\subsection{Sentenças com efeitos aditivos}

Dentre as situações de inconstitucionalidade para o futuro e a declaração de inconstitucionalidade sem nulidade do direito alemão que visam evitar um vazio jurídico, interessa nessa análise, a sentença com efeitos aditivos, uma espécie de sentença manipulativa. ${ }^{80}$

Tal sentença denominada por Mauro Capelletti de sentenças normativas trata de um fenômeno recente na jurisdição constitucional, demonstra o aspecto mais atraente e o mais problemático da falta de efetividade constitucional dos direitos

${ }^{78}$ ROMBOLI, Roberto. El control de constitucionalid de las leyes em Italia. Teoría y Realidad Constitucional. N. 4, p. 179-205, $2^{\circ}$ semestre 1999. Monográfico. El tribunal constitucional.

79 URBANO, Maria Benedita Malaquias Pires. Sentenças intermédias: para além de Kelsen, mas ainda aquém de uma nova teoria da separação dos poderes. In livro de homenagem ao Doutor J. J. Gomes Canotilho. Vol. 3. Coimbra (no prelo).

80 URBANO, Maria Benedita Malaquias Pires. Sentenças intermédias: para além de Kelsen, mas ainda aquém de uma nova teoria da separação dos poderes. In livro de homenagem ao Doutor J. J. Gomes Canotilho. Vol. 3. Coimbra (no prelo). 
AMORIM, Camila Silva de. Efetividade das normas constitucionais e sentenças com efeitos aditivos na justiça constitucional portuguesa e brasileira. Revista Eletrônica Direito e Política, Programa de Pós-Graduação Stricto Sensu em Ciência Jurídica da UNIVALI, Itajaí, v.10, n.2, $1^{0}$ quadrimestre de 2015. Disponível em: www.univali.br/direitoepolitica - ISSN 1980-7791.

fundamentais, que é justamente o encontro entre os Poderes Legislativo e Judiciário e suas funções, a lei e a sentença, a norma e julgamento, o legislador e o juiz. ${ }^{81}$

Colapietro identifica o problema já citado das várias nomenclaturas como sentenças normativas, interpretativas, sentenças criativas, sentenças integrativas e sentenças lei; ${ }^{82}$ adotaremos a terminologia de sentenças aditivas do direito italiano.

Blanco de Morais subdivide as sentenças aditivas em sentenças aditivas de garantia e de prestação, sentenças aditivas sem redução de texto e sentenças aditivas de caráter corretivo e de conteúdo integrativo. ${ }^{83}$

No direito italiano há uma subdivisão das sentenças aditivas em sentenças aditivas de princípios (indica o princípio não desenvolvido pelo legislador), substitutiva (inova o ordenamento de eficácia erga omnes) e monitória (fixa condições ao legislador para suprir a deficiência legislativa). ${ }^{84}$

Importa frisar que no ordenamento italiano não há norma expressa de controle de constitucionalidade por omissão, diferentemente do que ocorre em Portugal e no Brasil, o que leva o legislador a duas soluções: ou deixa o vazio constitucional ou invade a esfera do legislador preenchendo a lacuna. ${ }^{85}$

O surgimento das sentenças aditivas se deve:

el horror vacui, esto es, el temor a crear vacíos normativos; el temor a crear situaciones que propicien resultados aún más danosos constitucionalmente hablando de los que derivan de la inconstitucionalidade que se trate de eliminar;

81 CAPELLETTI, Mauro. O controle constitucional de constitucionalidade no direito comparado. Tradução Aroldo Plínio Gonçalves. Porto Alegre: S. A. Fabris. 1992, p. 26.

${ }^{82}$ COLAPIETRO, Carlo. Le sentenze additive e sostitutive della Corte Costituzionale. Pisa: Pacini Editores, 1990, p.16.

83 BLANCO, Carlos Blanco de. As sentenças intermédias na justiça constitucional. Lisboa: AAFDL, 2009, p. 48.

${ }^{84}$ PELICIOLI, Angela Cristina. A sentença normativa na jurisdição constitucional: o Supremo Tribunal Federal como legislador positivo. São Paulo: LTr, 2008, p. 192-195.

${ }^{85}$ PELICIOLI, Angela Cristina. A sentença normativa na jurisdição constitucional: o Supremo Tribunal Federal como legislador positivo. São Paulo: LTr, 2008, p. 192-195. 
AMORIM, Camila Silva de. Efetividade das normas constitucionais e sentenças com efeitos aditivos na justiça constitucional portuguesa e brasileira. Revista Eletrônica Direito e Política, Programa de Pós-Graduação Stricto Sensu em Ciência Jurídica da UNIVALI, Itajaí, v.10, n.2, $1^{\circ}$ quadrimestre de 2015. Disponível em: www.univali.br/direitoepolitica - ISSN 1980-7791.

la salvaguarda de la libertad de configuración del legislador, que se pone especialmente de manifiesto allí donde la normación del legislador constitucional posibilita desarrollos plurales; e, el coste financeiro de algunas sentencias. ${ }^{86}$

A sentença aditiva seria, então, um tipo de sentença manipulativa, na qual o Tribunal declara inconstitucional a norma por aquilo que ela não prevê adicionando texto à disposição da lei para que não padeça de vício de inconstitucionalidade.

Segundo Fátima de Sá as sentenças aditivas:

podem ser definidas como aquelas que declaram que ao preceito impugnado the falta algo para ser conforme à Constituição, devendo, assim, o preceito ser aplicado incluindo aquilo que Ihe faltava. Nesse passo, é declarada a inconstitucionalidade do preceito na parte em que não inclui algo ou alguém. Censuram, dessa forma, uma omissão legislativa inconstitucional, entendida aqui como um silêncio parcial do legislador, que cria uma situação contrária à Constituição, pois, na maior parte das vezes, violam o princípio da igualdade. Em sentido amplo, podem ser descritas, conforme Revorio, como aquelas que sem afetar o texto da decisão impugnada, produzem um efeito de extensão ou ampliação de seu conteúdo normativo, assinalando que tal dispositivo deve incluir algo que no texto da disposição não prevê expressamente. Assim, a inconstitucionalidade é declarada não naquilo que a norma prescreve, mas, contrariamente, a fiscalização recai no fato da norma não prever aquilo que deveria estar previsto para ser conforme à Constituição. ${ }^{87}$

Para Angela Cristina Pelicioli, visa manter o texto constitucional e evitar um vazio jurídico, para isso o legislador: manipula os efeitos da declaração de inconstitucionalidade recriando norma geral e abstrata retroativamente ou a partir de outro momento que definir, interpreta conforme a Constituição e

86 SEGADO, Francisco Fernández. La justicia constitucional: una visión de derecho comparado. Tomo I. Madrid: Dykison, 2008, p. 689-691.

87 SÁ, Fátima de. "Omissões inconstitucionais e sentenças aditivas". In: BLANCO, Carlos Blanco de. As sentenças intermédias na justiça constitucional. Lisboa: AAFDL, 2009, p. 428-429. 
AMORIM, Camila Silva de. Efetividade das normas constitucionais e sentenças com efeitos aditivos na justiça constitucional portuguesa e brasileira. Revista Eletrônica Direito e Política, Programa de Pós-Graduação Stricto Sensu em Ciência Jurídica da UNIVALI, Itajaí, v.10, n.2, 10 quadrimestre de 2015. Disponível em: www.univali.br/direitoepolitica - ISSN 1980-7791.

declara a inconstitucionalidade parcial sem redução de texto da lei ou ato normativo. ${ }^{88}$

Gilmar Ferreira Mendes defende a atuação do Supremo Tribunal Federal com legislador positivo, diz:

É certo que a declaração de nulidade não configura técnica adequada para a eliminação da situação inconstitucional nesses casos de omissão inconstitucional. Uma cassação aprofundaria o estado de inconstitucionalidade. A técnica da declaração de nulidade, concebida para eliminar a inconstitucionalidade causada pela intervenção indevida no âmbito de proteção dos direitos individuais, mostra-se insuficiente como meio de superação da inconstitucionalidade decorrente da omissão legislativa. ${ }^{89}$

Para Carlos Blanco de Moraes, a decisão com efeito aditivo só se legitima quando complementa, adiciona a norma preceito já existente, pois não é dado ao julgador inovar no ordenamento jurídico com a criação de normas. ${ }^{90}$

Diz Rui de Medeiros:

Efectivamente, embora parte da doutrina admita que as decisões modificativas são proferidas no exercício de um poder discricionário do Tribunal Constitucional e se contente em pedir aos juízes constitucionais que usem a sua liberdade de escolha com parcimônia, numerosos autores esforçam-se por sublinhar que não está em causa o exercício de uma função substancialmente criativa ex nihil, verificando-se tãosomente a extração de um quid iuris já presente - de modo cogente e vinculativo para o próprio legislador - no ordenamento jurídico. Nessa perspectiva, o órgão de controlo, ao modificar a lei, não actua como se fosse legislador, já que não possui aquele grau de liberdade de

\footnotetext{
${ }^{88}$ PELICIOLI, Angela Cristina. A sentença normativa na jurisdição constitucional. Disponível em: www2.senado.gov.br/bdsf/, Brasília a 44 n. 174 abr./jun. 2007. Acesso em 20 de janeiro de 2012. Tal legitimidade de atuação do poder judiciário, segundo a doutrinadora, deriva do princípio da efetividade e na teoria dos poderes implícitos (sempre que os fins exigirem, os meios são justificados). PELICIOLI, Angela Cristina. A sentença normativa na jurisdição constitucional: - Supremo Tribunal Federal como legislador positivo. São Paulo: LTr, 2008, p. 240.

${ }^{89}$ MENDES, Gilmar Ferreira. Jurisdição Constitucional no Brasil: o problema da omissão legislativa inconstitucional. Disponível em: www.portaldeperiodicos.idp.edu.br. Acesso em 20 de janeiro de 2012.

90 BLANCO, Carlos Blanco de. As sentenças intermédias na justiça constitucional. Lisboa: AAFDL, 2009, p. 363.
} 
AMORIM, Camila Silva de. Efetividade das normas constitucionais e sentenças com efeitos aditivos na justiça constitucional portuguesa e brasileira. Revista Eletrônica Direito e Política, Programa de Pós-Graduação Stricto Sensu em Ciência Jurídica da UNIVALI, Itajaí, v.10, n.2, $1^{\circ}$ quadrimestre de 2015. Disponível em: www.univali.br/direitoepolitica - ISSN 1980-7791.

opção para definir o escopo legal que é atributo do legislador. O quid iuris adiectum, ainda que não explicitado formalmente na disposição ou no texto (verba legis), está já presente, e in modo obbligante, no próprio sistema. ${ }^{91}$

Segundo o doutrinador as sentenças manipulativas e aditivas têm como limites a proibição de inovação jurídica e vinculação do juiz ao ordenamento jurídico delineado pelo legislador. ${ }^{92}$

A sentença que gera efeitos aditivos seria, então, aquela que decorre do reconhecimento da omissão legislativa, ainda que parcial, acrescentando o elemento ausente, seja uma norma ou um princípio que se adéque ao caso concreto.

As sentenças aditivas consistem em fazer uma interpretação extensiva do âmbito de aplicação do preceito legal impugnado a fim de conformá-lo à Constituição: após a interpretação, a regra é aplicável a um maior número de hipóteses do que as compreendidas em abstrato pelo enunciado legal. ${ }^{93}$

"Senza dire che, quanto à eliminazione di omissioni, il giucice constituzionale deve di necessità essere molto cauto perché talune omissioni se pretaro ad essere contruite secundo un grado altíssimo di arbítrio". ${ }^{94}$

Todavia, nessa conjuntura, torna-se possível que os tribunais constitucionais usem e abusem de sentenças manipulativas, modeladoras dos efeitos da declaração de inconstitucionalidade, ou quando fixam em termos estritos os pressupostos da inconstitucionalidade de uma norma, corre-se sempre o risco de as folgas democráticas de apreciação política serem restringidas a ponto de os

\footnotetext{
${ }^{91}$ MEDEIROS. Apud. Supremo Tribunal Federal. MI 708, Rel. Min. Gilmar Mendes, Dj. 25/10/2007. Voto do Ministro Gilmar Mendes, p. 242.

92 MEDEIROS. Apud. BONSAGLIA, Alexandre Antonucci. Sentenças aditivas na jurisprudência do Supremo Tribunal Federal. Monografia apresentada na Sociedade Brasileira de Direito Público (SBDP). 2010, p. 16.

${ }^{93}$ ELIA, Leopoldo. Constitucionalismo cooperativo, racionalidade y sentencias aditivas. In División de poderes e interpretación. Madri. Tecnos, 1987, p. 77.

${ }^{94}$ ELIA, Leopoldo. Constitucionalismo cooperativo, racionalidade y sentencias aditivas. In División de poderes e interpretación. Madri. Tecnos, 1987, p. 321.
} 
AMORIM, Camila Silva de. Efetividade das normas constitucionais e sentenças com efeitos aditivos na justiça constitucional portuguesa e brasileira. Revista Eletrônica Direito e Política, Programa de Pós-Graduação Stricto Sensu em Ciência Jurídica da UNIVALI, Itajaí, v.10, n.2, 10 quadrimestre de 2015. Disponível em: www.univali.br/direitoepolitica - ISSN 1980-7791.

tribunais constitucionais merecerem a censura de se transformarem em 'superlegisladores'.95

O que pretende nas sentenças aditivas é garantir o princípio da igualdade, presumivelmente vulnerado por uma interpretação não expansiva, mas estrita, do preceito. Mas está claro que nestes casos o Juiz Constitucional também poderia salvar a igualdade simplesmente anulando o texto legal. Se em vez disso opta por fazê-lo extensível ao grupo discriminado (sentença aditiva) é porque considera que a simples anulação do preceito in toto pode causar prejuízos imediatos para todos aqueles a quem o preceito outorga direitos. ${ }^{96}$

Mesmo desviando-se de sentenças aditivas em matéria penal (assim como no direito italiano) e sob argumento de defesa da Constituição e, ainda que em nome da igualdade, entende-se que o Tribunal Constitucional atua como um autêntico legislador positivo, pois cria uma nova norma para os aplicadores do direito, mas que não foi estabelecida pelo legislador.

De acordo com Marina Abellán, além de atuar como legislador positivo faz valorações políticas. O que segundo a doutrinadora pode gerar uma situação de insegurança jurídica de consequência não desejada pela interpretação constitucional. Haja vista que os direitos criados, necessitam de regulamentação e previsões econômicas, dado que o Tribunal Constitucional pode legislar, mas não pode com a previsão e precisão do legislador. ${ }^{97}$

Ademais, ressalta Maria Benedita Urbano em notas conclusivas que as sentenças intermédias favorecem a desresponsabilização do legislador ordinário. "A inércia e o imobilismo do legislador ordinário são recorrentemente apontados como a razão da atitude mais criativa do juiz constitucional. Mas, e se esta atitude

95 CANOTILHO, Joaquim José Gomes. Jurisdição Constitucional e intranquilidade discursiva. In Perspectivas constitucionais: nos 20 anos da Constituição de 1976, org. Jorge Miranda. Coimbra: Coimbra Editora, 1996, p. 871-887.

96 ABELLÁN, Marina Gascón. Os limites da justiça constitucional: a invasão do âmbito político. Revista brasileira de estudos constitucionais-RBEC. ano 1. n. 1. jan./mar. 2007. Belo Horizonte: Fórum, p. 71-92, 2007.

97 ABELLÁN, Marina Gascón. Os limites da justiça constitucional: a invasão do âmbito político. Revista brasileira de estudos constitucionais-RBEC. ano 1. n. 1. jan./mar. 2007. Belo Horizonte: Fórum, p. 71-92, 2007. 
AMORIM, Camila Silva de. Efetividade das normas constitucionais e sentenças com efeitos aditivos na justiça constitucional portuguesa e brasileira. Revista Eletrônica Direito e Política, Programa de Pós-Graduação Stricto Sensu em Ciência Jurídica da UNIVALI, Itajaí, v.10, n.2, $1^{0}$ quadrimestre de 2015. Disponível em: www.univali.br/direitoepolitica - ISSN 1980-7791.

passiva do legislador escondesse, afinal, a vontade de evitar escolhas políticas difíceis? " 98

Importa ressaltar, também as objeções de Luís Roberto Barroso à crescente intervenção judicial, especialmente no Brasil, onde a judicialização colocaria em risco a legitimidade democrática, geraria uma politização indevida da justiça e quais seriam os limites da capacidade institucional do Judiciário. ${ }^{99}$

Isso porque os membros do judiciário não são agentes públicos eleitos sua atuação decorre da letra da Constituição e pelo balanceamento das regras do jogo democrático de forma que juízes e tribunais só atuam legitimamente quando fundamentam racionalmente suas decisões com base na Constituição. Ademais, o juiz não tem vontade política própria e deve ser deferente para com as decisões respeitando a presunção de validade das leis, e ainda, deve estar em sintonia com sentimento social, sempre que possível. ${ }^{100}$

Por fim, quanto aos limites do judiciário, a capacidade institucional envolve a determinação de qual Poder está mais habilitado a produzir a decisão em determinada matéria e quais os efeitos sistêmicos (impacto de determinadas decisões). A expansão do judiciário não deve desviar a atenção da real disfunção que aflinge a democracia, sobretudo a brasileira: a crise de representatividade, legitimidade e funcionalidade do poder legislativo. Precisa-se de uma reforma política. E essa não pode ser feita por juízes. ${ }^{101}$

Defende-se uma delimitação restrita da possibilidade de proferir sentenças com efeitos aditivos, aceitas excepcionalmente, no Tribunal Constitucional Português, cujo sistema de controle de constitucionalidade guarda semelhanças com o

98 URBANO, Maria Benedita Malaquias Pires. In livro de homenagem ao Doutor J. J. Gomes Canotilho. Vol. 3. Coimbra (no prelo).

${ }^{99}$ BARROSO, Luís Roberto. Judicialização, ativismo judicial e legitimidade democrática. In Justiça Constitucional. Pressupostos teóricos e análises concretas. Belo Horizonte, 2007, p. 241254.

${ }^{100}$ BARROSO, Luís Roberto. Judicialização, ativismo judicial e legitimidade democrática. In Justiça Constitucional. Pressupostos teóricos e análises concretas. Belo Horizonte, 2007, p. 241254.

${ }^{101}$ BARROSO, Luís Roberto. Judicialização, ativismo judicial e legitimidade democrática. In Justiça Constitucional. Pressupostos teóricos e análises concretas. Belo Horizonte, 2007, p. 241254. 
AMORIM, Camila Silva de. Efetividade das normas constitucionais e sentenças com efeitos aditivos na justiça constitucional portuguesa e brasileira. Revista Eletrônica Direito e Política, Programa de Pós-Graduação Stricto Sensu em Ciência Jurídica da UNIVALI, Itajaí, v.10, n.2, $1^{\circ}$ quadrimestre de 2015. Disponível em: www.univali.br/direitoepolitica - ISSN 1980-7791.

brasileiro diante da omissão legislativa sem ferir o princípio da separação dos poderes e alvitrar a discricionariedade do julgador.

\section{CONSIDERAÇÕES FINAIS}

O presente trabalho teve como finalidade avaliar a atuação do órgão guardião da Carta Constitucional como legislador positivo, em outras palavras, em que momento a atuação do poder jurisdicional vai além da interpretação para a criação da norma jurídica faltante como se legislador fosse.

Essa atuação se justifica em nome da justiça, do princípio da igualdade e da tutela das situações fáticas face ao jurisdicionado? Por que a simples declaração de inconstitucionalidade por omissão não é suficiente para atuação do legislador e, então, a busca pela efetividade da norma constitucional se concretizaria em conformidade com a separação dos poderes?

Com base no exposto, entende-se que a edição, cada vez mais frequente, de sentenças aditivas pelo judiciário, além de macular o princípio estruturante estabelecido nessas Constituições, o da separação dos poderes, trazem ao juiz um poder não previsto constitucionalmente e de consequências práticas que somente podem ser avaliadas pelo legislador.

A descrença no poder legislativo, sobretudo no caso brasileiro, não pode inverter a lógica constitucional diante do "não fazer". Porém, consideram-se válidas as técnicas previstas nas Constituições e nas leis no controle da omissão e o seu aperfeiçoamento como desenvolvimento da atividade interpretativa do juiz, mas inadmissível a sua atuação de criar lei em face da omissão legislativa, notadamente nos casos de omissão total.

Tanto que é possível a responsabilização civil do legislador nos casos de omissão a exemplo do direito português, reforçando a tese que cabe a ele elaborar as leis. 
AMORIM, Camila Silva de. Efetividade das normas constitucionais e sentenças com efeitos aditivos na justiça constitucional portuguesa e brasileira. Revista Eletrônica Direito e Política, Programa de Pós-Graduação Stricto Sensu em Ciência Jurídica da UNIVALI, Itajaí, v.10, n.2, $1^{0}$ quadrimestre de 2015. Disponível em: www.univali.br/direitoepolitica - ISSN 1980-7791.

No combate à falta de efetividade das normas constitucionais em decorrência das omissões normativas deve-se cobrar das autoridades públicas competentes a implementação dos direitos em conformidade com a Constituição, tarefa incumbida à sociedade e ao próprio judiciário na concretização de um Estado Democrático de Direito.

\section{REFERÊNCIAS DAS FONTES CITADAS}

ABELLÁN, Marina Gascón. Os limites da justiça constitucional: a invasão do âmbito político. Revista brasileira de estudos constitucionais-RBEC. ano 1 . n. 1. jan./mar. 2007. Belo Horizonte: Fórum, p. 71-92, 2007.

BARROSO, Luís Roberto. A doutrina brasileira da efetividade. Constituição e democracia: estudos em homenagem ao professor J. J. Gomes Canotilho. São Paulo: Malheiros, 2006.

Novos paradigmas e categorias da interpretação constitucional. In Intepretação Constitucional. Reflexões sobre (a nova hermenêutica). Salvador: Edições JusPodivm, 2010.

O direito constitucional e a efetividade de suas normas. Limites e possibilidades da Constituição brasileira. 7. ed. Rio de Janeiro: Renovar, 2003.

Judicialização, ativismo judicial e legitimidade democrática. In

Justiça Constitucional. Pressupostos teóricos e análises concretas. Belo Horizonte, 2007.

BICKEL, Alexander. The Least Dangerous Branch: The Supreme Court at the Bar of Politics. Yale Univ. Press, New Haven, 1962.

BONSAGLIA, Alexandre Antonucci. Sentenças aditivas na jurisprudência do Supremo Tribunal Federal. Monografia apresentada na Sociedade Brasileira de Direito Público (SBDP). 2010.

BRAGA, Valeschka e Silva. A omissão legislativa no Brasil e no Direito Comparado Debates em Direito Público. In Revista de Direito dos Advogados da União, v. 4, n. 4, p. 99-118. out. 2005.

CANOTILHO, J. J. Gomes. Direito Constitucional e Teoria da Constituição. Edições Almedina. Coimbra, 7. ed. 2003.

Jurisdição Constitucional e intranquilidade discursiva. In Perspectivas constitucionais: nos 20 anos da Constituição de 1976, org. Jorge Miranda. Coimbra: Coimbra Editora, 1996. 
AMORIM, Camila Silva de. Efetividade das normas constitucionais e sentenças com efeitos aditivos na justiça constitucional portuguesa e brasileira. Revista Eletrônica Direito e Política, Programa de Pós-Graduação Stricto Sensu em Ciência Jurídica da UNIVALI, Itajaí, v.10, n.2, $1^{\circ}$ quadrimestre de 2015. Disponível em: www.univali.br/direitoepolitica - ISSN 1980-7791.

CAPELLETTI, Mauro. O controle constitucional de constitucionalidade no direito comparado. Tradução Aroldo Plínio Gonçalves. Porto Alegre: S. A. Fabris. 1992.

CARBONELL, Miguel. Neoconstitucionalismo: elementos para uma definición. In 20 anos da Constituição brasileira. São Paulo: Saraiva, 2009.

CARVALHO NETTO, Menelick de. Requisitos paradigmáticos da interpretação jurídica sob o paradigma do Estado democrático de direito. Revista de Direito Comparado, Belo Horizonte, n. 3, mai. 1999.

CLÈVE, Clèmerson Merlin. A fiscalização abstrata da constitucionalidade no direito brasileiro. 2 ed. rev. atual e ampl. São Paulo: RT, 2000.

COLAPIETRO, Carlo. Le sentenze additive e sostitutive della Corte Costituzionale. Pisa: Pacini Editores, 1990.

COOLEY, Thomas M. Treatise on the constitucional limitations. 7 ed. Boston, Brown and Co, 1890.

CRISAFULLI, Vezio. La Constituzione e le sue disposizioni di principio. Milão, Dott. A. Giuffrè Editore, 1952.

ELIA, Leopoldo. Le sentenze additive e la piú recente giurisprudenza della Corte Costituzionale. In Scritti sulla giustizia costitucionale in onore di Vezio Crisafulli. Pádua. CEDAM; 1985.

Constitucionalismo cooperativo, racionalidade y sentencias aditivas. In División de poderes e interpretación. Madri. Tecnos, 1987.

KIM, Richard Pae. Neoconstitucionalismo: hermenêutica constitucional e atividade jurisdicional na tutela dos direitos do cidadão. In Revista Ajuris. Associação dos Juízes do Rio Grande do Sul. V. 36. N. 116, p. 269-290. Dezembro 2009.

LENZA, Pedro. Direito Constitucional Esquematizado. 13. ed. atual e ampl. São Paulo: Saraiva, 2009.

MENÉNDEZ, Ignacio Villaverde. La inconstitucionalidade por omisión de los silêncios legislativos, in Anuario de Derecho Constitucional y Parlamentario, no 8, 1996, p. 3961-3999.

MENDES, Gilmar Ferreira. Jurisdição Constitucional no Brasil: o problema da omissão legislativa inconstitucional. Acesso em: www.portaldeperiodicos.idp.edu.br.

MIRANDA, Jorge. Manual de Direito Constitucional. Vol. VI, $3^{a}$ ed. Coimbra, Coimbra Editora, 2008.

MORAES, Alexandre. Jurisdição Constitucional e tribunais constitucionais. Garantia Suprema da Constituição. 2.ed. São Paulo: Atlas, 2003. 
AMORIM, Camila Silva de. Efetividade das normas constitucionais e sentenças com efeitos aditivos na justiça constitucional portuguesa e brasileira. Revista Eletrônica Direito e Política, Programa de Pós-Graduação Stricto Sensu em Ciência Jurídica da UNIVALI, Itajaí, v.10, n.2, $1^{\circ}$ quadrimestre de 2015. Disponível em: www.univali.br/direitoepolitica - ISSN 1980-7791.

MORAIS, Carlos Blanco de. Justiça Constitucional. Tomo I: Garantia da Constituição e controlo da constitucionalidade. Coimbra: Coimbra Editora, 2002.

NADAIS, Antônio, VITORINO, Antônio, CANAS, Vitalino. Lei sobre organização, funcionamento e processo no tribunal constitucional. Lisboa: AAEDL, 1984.

PELICIOLI, Angela Cristina. A sentença normativa na jurisdição constitucional. Disponível em: www2.senado.gov.br/bdsf/, Brasília a 44 n. 174 abr./jun. 2007.

A sentença normativa na jurisdição constitucional: o Supremo Tribunal Federal como legislador positivo. São Paulo: LTr, 2008.

PIOVESAN, Flávia. Proteção judicial contra omissões legislativas: ação direta de inconstitucionalidade por omissão e mandado de injunção. 2 ed. rev., atual e ampl. São Paulo: Editora Revista dos Tribunais, 2003.

ROMBOLI, Roberto. El control de constitucionalid de las leyes en Italia. Teoría y Realidad Constitucional. N. 4, p. 179-205, $2^{\circ}$ semestre 1999. Monográfico. El tribunal constitucional.

RUIZ, Mortati Maria Ángeles Ahumada, El control de constitucionalidade de las omisiones legislativas, in Revista del Centro de Estudios Constitucionales, vol. 8, Madri, Centro de Estudios Constitucionales, p. 170-174, jan.-abr. 1991.

SÁ, Fátima de. "Omissões inconstitucionais e sentenças aditivas". In: BLANCO, Carlos Blanco de. As sentenças intermédias na justiça constitucional. Lisboa: AAFDL, 2009.

SARMENTO, Daniel. Interpretação constitucional, pré-compreensão e capacidades institucionais do intérprete. In Intepretação Constitucional. Reflexões sobre (a nova hermenêutica). Salvador: Edições JusPodivm, 2010.

SEGADO, Francisco Fernández. La justicia constitucional: una visión de derecho comparado. Tomo I. Madrid: Dykison, 2008.

SILVA, Jorge Pereira. Dever de legislar e Protecção Jurisdicional contra Omissões Legislativas. Lisboa, Universidade Católica, 2003.

SILVA, José Afonso da. Aplicabilidade das normas constitucionais. 7 ed. São Paulo: Malheiros, 2007.

STRECK, Lênio. Hermenêutica, Constituição, Autonomia do Direito e o Direito Fundamental a obter respostas adequadas (corretas). In Intepretação Constitucional. Reflexões sobre (a nova hermenêutica). Salvador: Edições JusPodivm, 2010.

TEMER, Michel. Elementos de um direito constitucional. 10. ed. São Paulo: 1993. 
AMORIM, Camila Silva de. Efetividade das normas constitucionais e sentenças com efeitos aditivos na justiça constitucional portuguesa e brasileira. Revista Eletrônica Direito e Política, Programa de Pós-Graduação Stricto Sensu em Ciência Jurídica da UNIVALI, Itajaí, v.10, n.2, $1^{\circ}$ quadrimestre de 2015. Disponível em: www.univali.br/direitoepolitica - ISSN 1980-7791.

URBANO, Maria Benedita Malaquias. Sentenças intermédias: para além de Kelsen, mas ainda aquém de uma nova teoria da separação dos poderes. In Livro de homenagem ao Doutor J. J. Gomes Canotilho (no prelo).

ZAVASASCKI, Teori Albino. Eficácia das sentenças na jurisdição constitucional. São Paulo: Editora Revista dos Tribunais, 2001.

Submetido em: Agosto/2014

Aprovado em: Fevereiro/2015 